\title{
ANALYSIS OF THE ROBUSTNESS OF AUSTRALIA ECONOMY AND ENERGY SUPPLY/DEMAND FLUCTUATION
}

\author{
Alireza Aslani ${ }^{1}$ Mohsen Rezaee ${ }^{12}$ Seyed Mostafa Mortazavi ${ }^{1}$
}

\begin{abstract}
Energy has a strategic role in social and economic development of the countries. Due to the high dependency of energy supply to fossil fuels, fluctuations in prices and supply have macro/micro-economics effects for both energy exporters and importers. Therefore, understanding economic stability based on energy market changes is an important subject for policy makers and researchers. As the competitiveness of Australia products/services has high dependency on energy prices, analyzing the relationships of economics robustness with fossil fuel fluctuations is important for the policy makers and researchers. In this paper, the researchers investigate the effects of energy changes on Australian economics. In this regard, first, the impact of oil price on macro-economic parameters is discussed. After that, the main issues related to energy economics including resilience of the energy sector, energy policies, economics analysis of the energy sector, electricity markets are discussed.
\end{abstract}

Keywords: Energy Economics, Robustness, Australia

\section{Introduction}

Energy plays an important role in human societies. Every human activitiesand all economic sectors like transportation, communication, security, health, delivery systemsand etc. require constant supplies of energy. Diverse energy sources make existence and life possible for creatures and civilizations.Population growth and improvements in the quality of life have

${ }^{1}$ Department of Renewable Energy and Environment, Faculty of New Sciences and Technologies, University of Tehran, Tehran; alireza.aslani@uva.fi

${ }^{2}$ Department of Production, Faculty of Technology, University of Vaasa, Finland 
increased the consumption of energy. Life without proper access to various energy sources is completely intolerable for human beings(Demirbaş,2006). Therefore, the intense dependence of industrialized countries on energy resources like fossil fuels, has caused diminishing fossil fuel reserves and environmental impacts such as pollutions, global climate change and health risks (Hoppe, et al.,2016).Renewable energy sources like biomass, hydropower, geothermal, solar, wind and marine energies are considered as a clean or inexhaustible energy resources that supply $14 \%$ of the total world energy demand (Panwar, et al.,2011, Demirbas,2016).

Many researches suggest that oil pricefluctuations have considerable consequences oneconomic factors. These consequences are expectedto be different in oil importing and in oil exportingcountries .The transmission mechanisms through which oil prices have animpact on real economic activity include both supplyand demand channels. The supply side effects arerelated to the fact that crude oil is a basic input toproduction, and consequently an increase in oilprice leads to a rise in production costs that inducesfirms to lower output. Oil price changes also entailside effects on consumption and investment(Jiménez-Rodríguez and Sánchez,2005, Krishnan,2016).

One of the countries that energy plays an important role in its economy is Australia.Australia is the sixth largest country in the world in terms of land mass at 2.97 million square miles. Its population with the yearly growth of 1.57 $\%$ is around 24 million people in 2016. It has one of the strongest, most stable and diverse economy in the world. In 2015, Australia entered its 25th year of uninterrupted annual economic growth, averaging 3.3\% a year( Australian Government, Department of Foreign Affairs and Trade, 2016).Australia has plentiful and diverse energy resources, including large amounts of coal, gas, Liquefied Natural Gas, uranium and renewable energy(Hardisty, et al.,2012). Australia also produces large amounts of oil, but still imports most of its liquid fuels.Based on serious concerns about energy security,Australian has encouraged additional generation of electricity from renewable sources to fulfill their renewable energy target.The Office of the Renewable Energy Regulatoris a statutory authority established to oversee the implementation of the large scale renewable energy target and the small scale renewable energy scheme(Xueqian,2012).

Few works have been done on analyzing the various economic factors such as the impact of oil prices on gross domestic product (GDP), total and industrial energy consumption, inflation rate and unemployment rate.In this paper economic factors including the total energy consumption of Australia is investigated by using elasticity method. The electricity market isalso investigated. Finally challenges and opportunities are discussed. 


\section{Literature review}

Australia was the 21st largest exporter in the world in 2014. The exports of Australia have increased at an annualized rate of $7.7 \%$. The top exports of Australia are Iron Ore (60B \$), Coal Briquettes (37.2B \$), Petroleum Gas (16.3B \$), Gold (16.3B \$) and Crude Petroleum (9.1B \$). Its top imports are Refined Petroleum (16.6B \$), Crude Petroleum (16.2B \$), Cars (15.7B $\$$ ), Computers (7.37B \$) and Packaged Medicaments (6.5B \$) ( Worldbank, 2016). The 2015 release of supplementary data on international trade in services by the Australian Bureau of Statistics has allowed Department of Foreign Affairs and Trade to update its rankings of Australia's leading trading partners and top 25 exports and imports.

The growth of per capita GDP in Australia is highly dependent on fossil fuels like black coal, brown coal, crude oil, iron ore, other ore, processed metal, uranium and liquefied natural gas, which are the countries natural and mineral sources and form the major sources of Australia's export earnings(Alobaid, et al.,2017, Sahoo, et al.,2014).Plenty of researches have shown the direct relationship between energy consumption and per capita GDP growth. The total consumption of energy in Australia consists of domestic production and imports from external markets. During the 1970s and 1980s, the GDP growth rate of Australia declined because of the major oil price shocks and subsequent global economic recessions of 1980s.In 2012, Australia globally ranked 18th among the major energy consumers and 14th on a per capita GDP basis. Australia consumed $49 \%$ of its energy from domestic production and $51 \%$ from external sources via imports. However a great portion of this total energy consumption (about 38\%) is consumed by transport sector which has a significant impact on the total GDP growth rate of Australia. In 1960, the contribution of trade to Australia's GDP was $27 \%$, and in 2013 it increased to $41 \%$ of GDP(Australian Government, Department of Foreign Affairs and Trade, 2016). On the other hand, per capita trade increased consistently between 1960 and 1984 and from 1985 to 2012, per capita trade increased tremendously. A mining boom during the period 2000-09 is believed to be the main contributing factor to the tradesurge in Australia and it can be concluded that per capita trade contributes significantly to GDP growth in Australia.

Because of close relationship between global economic situation and domestic economic situation, an absence of exports plus imports of energy (the trade variable), the Australian macroeconomic production function may suffer from omitted variable bias.In 2012-13, Australia's net energy exports (exports minus imports) were $68 \%$ of its total energy production, and in 2013-14, energy exports accounted for $31 \%$ oftotal commodity exports in Australia. However Australia was the world's eighth-largest energy producer. Coal accounted for 
$59 \%$ of total energy production in Australia. On the other hand, Australia was also a net importer of crude oil and petroleum products, which accounted for $35 \%$ of oil consumption in 2012-13. Thesemineral resources act as inputs in the production process in industries at home and abroad, and thereby, contribute to GDP(Alobaid et al.,2017).

\section{Australian economy and energy investment}

Australia economy began to growth until 2008. The recent global financial crisis that began in 2008 has impacted industrialized and developing countries worldwide, but its impact on Australia has been considerably less than in many other countries. The government used several financial policies to minimizeits impact.Fig.1 shows economic growth in Australia. Australia has more resilient financial system that after 2008 crisis, rapidly GDP production increased, Inflation and interest rate decreased(Bollen, et al.,2015). Australia is the world's second largest exporter of coal, number three exporter of uranium, and number four exporter of gas. Australia is one of only three net energy exporters in the Organization for Economic Cooperation and Development (OECD).The energy sector is a major contributor to the economy, contributing between $16 \%$ and $17 \%$ of current GDP( Enegy policies of IEA countries, 2016). These exports provide export income, GDP growth, job positions, and helped Australia withstand the global financial crisis.

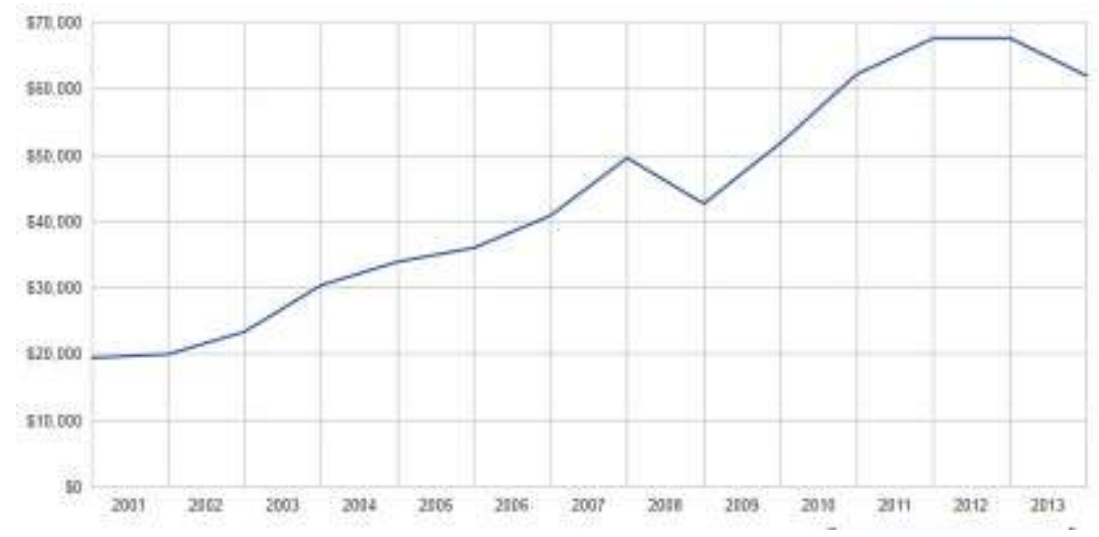

Fig.1. Australia GDP (current US\$)(worldbank, 2016)

Australia is the world's ninth largest energy production, eighteenth on energy consumption per person bases and seventeenth largest consumer of fossil energy resources. Renewable energy resources have small share of Australia's energy consumption. which represent about $4 \%$ of total energy consumption 
that are largely undeveloped (Azad, et al.,2014). Australia's Renewable Energy Target is designed to ensure that 20 percent of Australia's electricity comes from renewable sources by 2020. As Fig.2 and Fig.3 show, through the years 2004 to 2008 and also 2009 to 2013 by the increase of oil price, inflation rate in Australia has increased.This might be due to high dependency of Australia economy's on transportation also depends highly on petrol and by the increase of oil price, transportation would be more expensive and because of that goods would become more expensive that it causes inflation.

It can also be perceived from the charts that GDP growth rate has a good agreement with industrial production growth rate. But as industrial investments might take some time to reach to their productive stage, it might be evident that their growth rate would not be the same. Through the years 2008 to 2009 , by the sharp decrease of oil price, the GDP growth diminished and although there would be more fuel available for industry, it can be seen the industry growth has decreased and that would might be due to the fact that during that period the economy has shrank and it effects the industrial growth

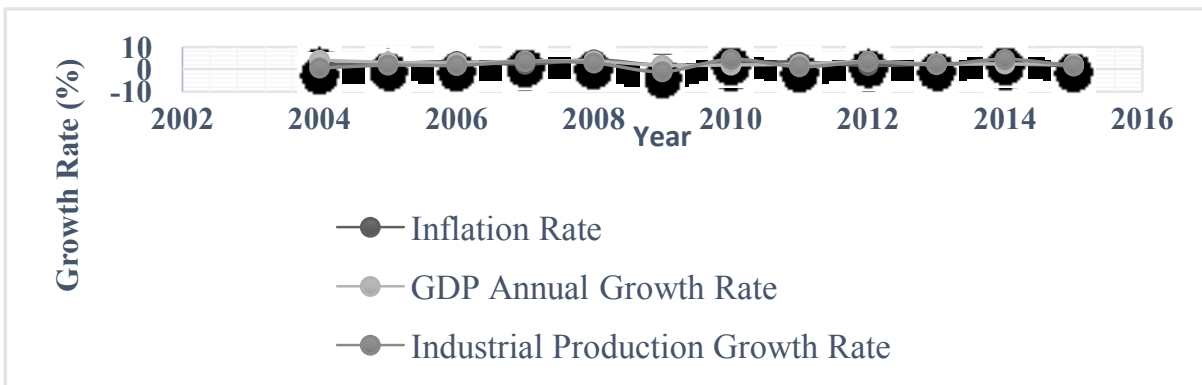

Fig. 2. Growth rates (\%) for GPD and Industry annual, and inflation rate (worldbank 2016)

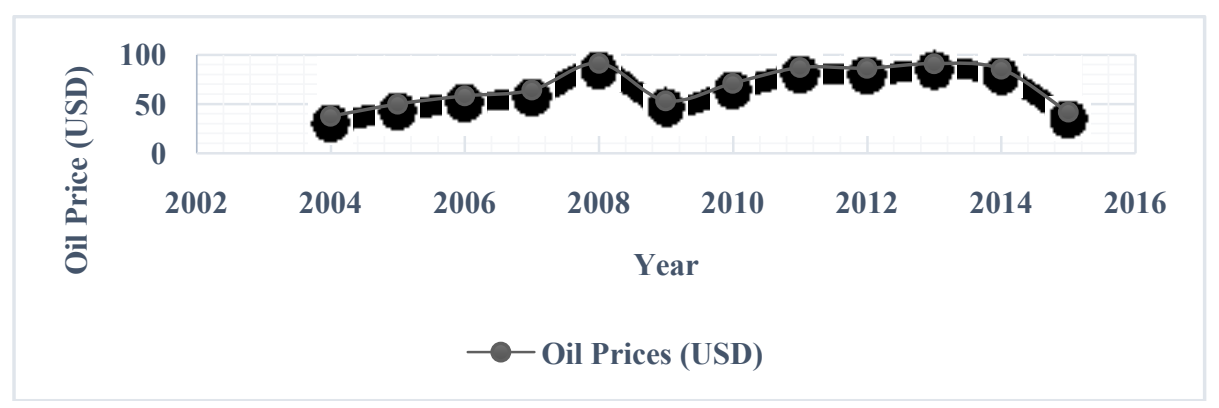

Fig.3. Crude oil price(USD/BBL)

(http://inflationdata.com/inflation/inflation_rate/historical_oil_prices_table.asp) 


\section{Energy policies}

Australian is one of OECD exporterenergy, and also should provide future energy consumption needs and economic growth demand with adequate, affordable and reliable energy.Thus,energy policy play significant role in economy. Therefore some programs has been designed. Some examples of Australia energy policy actions(Enegy policies of IEA countries , 2016) can be divided in 5 categorization.

\section{Economical and Financial}

\section{- Feed-in Tariff}

There are only a number of initiatives in every individual statesin order to boost economic growth and energy production. To date, there have been established numerous large scale Feed in Tariff (FIT) Scheme ran by Australian Capital Territory (ACT) specially for power generation (Specially small-scale generation) which provided the ACT government with power supply.

- R\&D Tax Incentive

The R\&D Tax Incentive scheme is established in almost all industry sectors. R\&D tax incentive belong toactivities thatprogress renewable energy development and operate in two level:Smaller companies (those with an aggregated turnover less than AUD20 million) can access a refundable 45 percent $\mathrm{R} \& \mathrm{D}$ tax offset and Larger companies (those with an aggregated turnover of AUD20 million of more) that can access a non-refundable 40 percent R\&D tax offset.

- Local Government Energy Efficiency Program

The Local Government Energy Efficiency Program (LGEEP) provided financial assistance to local governments for the installation of solar and heat pump hot water systems in community buildings and facilities, particularly where those authorities were situated in low socio economic or otherwise disadvantaged areas.

\section{Trade Actions}

Free Trade Agreements secure better market access to the world important markets, improve competitive position, assist economy growth and reduced import costs. Instantly,Australia free trade agreement with China regards to mining, tariffs will be removed from close to all Australian resources and energy products exported to China, including an eight per cent existing tariff on aluminum oxide and all tariffs on coking coal.

\section{Governmental Possessions and Organizations}

The National Electricity Market (NEM) runs across most part of Australia as a connected grid. A pool of electricity generators supply itand then sell electricity into a wholesale market. Smaller grids outside the NEM are 
managed by the relevant state or territory.State and territory electricity sectors havebeen separated into generation, poles, transmission, distribution and retail businesses. Electricity generation and retail sectors had some changes. In the other section study electricity market particularly.Only some sections of gas market are regulated by government and the gas pipelines are privately owned. Gas markets typically involve either long-term contracts between suppliers and major users, or regulated retail sales to small users.

\section{Regulations}

- Community Energy Efficiency Program

Government's climate change strategy was consist of Community Energy Efficiency Program. For completion projects that probe energy efficiency measures in council and community owned buildings, facilities and sites, a competitive merit-based grant program.

- Energy Efficiency Information Grants Program

Government's climate change strategy was consist of Energy Efficiency Information Grants. The Program assisted industry associations to provide practical, tailored energy efficiency information to small and medium enterprises, allowing them to reduce their operational costs by make decisions about energy efficiency.

- Low Income Energy Efficiency Program

Government's climate change strategy was consist of Low Income Energy Efficiency Program. For energy efficiency improvement of low income households and enable them to better manage their energy use, a competitive merit-based grant program was considered to provide grants to consortia of government, business and community organizations to trial approaches

- Energy Efficiency Opportunities

For evaluation and identification of large energy using corporationsenergy efficiency, The Energy Efficiency Opportunities program was considered.

\section{Research and Development}

- Australian Renewable Energy Agency (ARENA)

ARENA is an independent agency established by the Australian Government. It has two significant objectives: to increase the supply of renewable energy in Australia electricity market, and to improve the competitiveness of renewable energy technologies. It has funding for renewable energy development activities, researches and projects.

Energy Analysis of Australia based on the economic factors

The funding was provided to 5,310 schools to install renewable energy systems that consist of solar power systems, rainwater tanks and energy 
efficiency measures and helped to educate students about energy efficiency and renewable energy.

- Renewable Energy Bonus Scheme - Solar Hot Water Rebate

Under REBS, over 255,000 rebates was provided to eligible homeowners, landlords or tenants replace electric storage hot water systems with solar or heat pump hot water systems. Eligible households could claim a rebate of $\$ 1000$ for a solar hot water system or $\$ 600$ for a heat pump hot water system.

- Smart Grid, Smart City

The Smart Grid, Smart City project is part of the Australian Government's National Energy Efficiency Initiative and has delivered Australia's first commercial-scale smart grid. There were seven solar cities program worked in partnership with local government and industry consortia groups.

- Ethanol Production Grants (EPG) program

It was designed to develop production and consumption of ethanol as a sustainable alternative transport fuel in Australia from locally derived feedstock. It causes lower carbon emission, improve energy security and decrease rely on gasoline import.

- The relationship between economic factors and oil prices

One of the important economic factors in order to understand the effects of oilprices on macro-economics is elasticity. Elasticity is a significant factor that used in economicalstudies to measurement of how responsive an economic variable is to a change in another.Elasticity independent of the type of quantities being varied, soit isunitless ratio.It is calculating bythis simple equation:

$$
\text { Elasticity }=\frac{\text { percentage change in one variable }}{\text { percentage change in other variable }}
$$

In this study, the concept of elasticity is used to investigate the effect and relationship of crude oil price to GDP, energy consumption to GDP, and GDP to the industrial energy consumption to GDP. Table 1showsrelated data for elasticity analysis between 2004 to 2014 .

According Table 1, Elasticity ( $\left.\mathrm{P}_{\text {Oil }}-\mathrm{GDP}\right)$ is larger than 1. This means GDP is not dependent on oil prices and oil imports does not have very negative effect on GDP. In Australia oil consumption has fell. Coal production has grown strongly for domestic uses and exports. Coal can be converted to valuable sources e.g. electricity and natural gas. Also use of wind and solar energy continued to rise. It shows that government Research and Development actions had a good effect on replacing oil with renewable sources like bio ethanol and solar. 
Elasticity $\left(\mathrm{E}_{\text {Total }}-\mathrm{GDP}\right)$ is smaller than 1. Energy productivity (gross domestic product/energy consumption) rose. This means Australia use systems with good efficiency and GDP hasn't intense dependence of total energy consumption.The latest set of statistics shows that energy consumption in Australia fell. energy consumption fell in most states and territories.It has been shownthat government Regulations actions have good effect on optimal energy

Table1. related data for elasticity analysis between 2004 to 2014 (worldbank, www.industry.gov.au)

\begin{tabular}{|c|c|c|c|c|c|c|c|}
\hline Year & $\mathrm{P}_{\text {Oil }}(\$)$ & $\begin{array}{c}\text { GDP } \\
\text { (BUS\$) }\end{array}$ & $\begin{array}{c}\text { Total } \\
\text { Energy } \\
\text { Consumpti } \\
\text { on }(\mathrm{PJ})\end{array}$ & $\begin{array}{c}\text { Industry } \\
\text { Energy } \\
\text { Consumption } \\
\text { (PJ) }\end{array}$ & $\begin{array}{l}\text { Elasticity } \\
\left(\mathrm{P}_{\mathrm{Oil}}-\mathrm{GDP}\right)\end{array}$ & $\begin{array}{l}\text { Elasticity } \\
\text { (E }{ }_{\text {Total- }} \\
\text { GDP) }\end{array}$ & $\begin{array}{c}\text { Elasticity } \\
\text { (E Endustry- } \\
\text { GDP) }\end{array}$ \\
\hline 2004 & 37.66 & 612.69 & 5598.08 & 5400 & 2.51 & 0.05 & 0.18 \\
\hline 2005 & 50.04 & 693.07 & 5564.08 & 5530 & 2.13 & 0.34 & 0.63 \\
\hline 2006 & 48.3 & 746.88 & 5709.32 & 5800 & 0.71 & 0.20 & 0.06 \\
\hline 2007 & 64.2 & 853.05 & 5865.34 & 5750 & 1.8 & 0.07 & 0.07 \\
\hline 2008 & 91.48 & 1054.56 & 5964.62 & 5850 & 3.42 & 0.14 & 0.07 \\
\hline 2009 & 53.48 & 926.56 & 5862.55 & 5800 & 1.42 & 0.16 & 0.11 \\
\hline 2010 & 71.21 & 1142.25 & 5648.69 & 5950 & 1.03 & 0.01 & 0.01 \\
\hline 2011 & 87.04 & 1389.92 & 5638.49 & 5960 & 0.06 & 0.13 & 0.01 \\
\hline 2012 & 86.46 & 1537.48 & 5558.60 & 5965 & 3.16 & 0.29 & 0.05 \\
\hline 2013 & 91.17 & 1563.95 & 5586.33 & 5970 & 0.87 & 0.26 & 0.04 \\
\hline 2014 & 85.6 & 1454.68 & 5484.74 & 5955 & 6.46 & & \\
\hline \multicolumn{2}{|c|}{ Geometry mean } & & & & 1.3927 & 0.1146 & 0.0580 \\
\hline
\end{tabular}

consumption.It can interpret that Australian industrial systems have optimal energy consumption.Australia GDP isn't only rely on industry productions and it relay on services, business, agriculture, investment etc. Energy study shows growth in energy consumption in the mining, transport and services sectors was offset by a continued fall in energy use for electricity generation and manufacturing, as well as by households. Transport overtook the electricity supply sector as the largest energy user and industry energy consumption has good situation.

In this study, elasticity is also use to estimate 2020Australia totalenergy consumption. Australia GDP in 2020 forecast to be 1720 BUS \$ base on ( Trading Economics, 2016).According to equation 2, by considering GDP, energy consumption can be predicted in 2020.As a result of total energy consumption estimated by using elasticity method, it is estimated to be 12277.27 PJ. 
44 Analysis of the robustness of Australia economy and energy supply/demand fluctuation

$$
\operatorname{Elastisity~}\left(E_{\text {Total }}-G D P\right)=\frac{\frac{E 2020-E 2014}{E 2014}}{\frac{G D P 2020-G D P 2014}{G D P 2014}}
$$

\section{Electricity market}

Less than $7 \%$ of Australia's electricity production relies on the renewable energies. The electricity consumtion by different economical sectors as well as typeof customers have shown in Fig. 4.

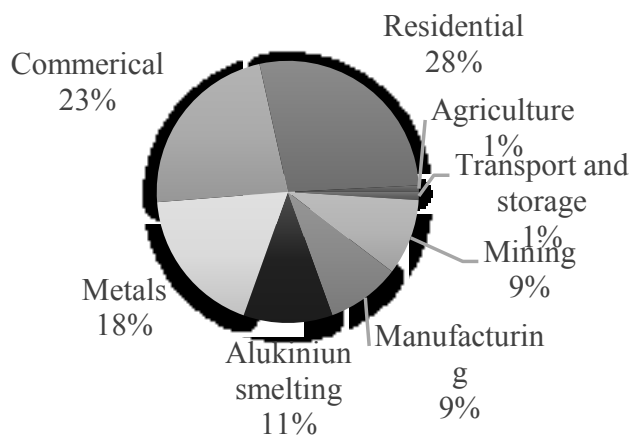

$$
\begin{array}{ll}
\text { Transport and storage } & \text { Mining } \\
\text { Manufacturing } & \text { Alukiniun smelting }
\end{array}
$$

Fig. 4. Electricity consumption by different sectors in Australia.

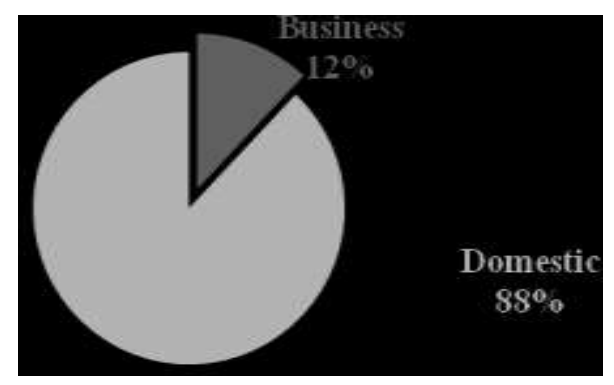

Fig. 5. The number of electricity customers by sector.

Most of electricity produced is consumed by residential and commercial sectors and Fig. 5 reveals that domestic sector is larger consumer of the produced energy. Therefore itit should be mentioned that for social, industrial and commercial growth. 
Australia government should provide electricity supply. The NEM began operating as a wholesale market for the supply of electricity to retailerselectricity to retailers and end-users in most parts of Australia.Some assets that comprise the NEM's infrastructure are owned and operated by state governments, and some are owned and operated under private business arrangements.

The NEM and gas market managed by Australian Energy Market Operator (AEMO) and set the National Electricity Law and the Rules. AEMO Created by the Council of Australian Governments and developed under the guidance of the Ministerial Council on Energy. AEMO set procedures and processes for market operations, power system security, network connection and access, pricing for network services in the NEM and national transmission planning are all prescribed in the Rules. Wholesale trading in electricity is conducted as a spot market where supply and demand are instantaneously matched in real-time through a centrally-coordinated dispatch process. Generators offer to supply the market with specific amounts of electricity at particular prices. Offers are submitted every five minutes of every day. From all offers submitted, AEMO determines the generators required to produce electricity based on the principle of meeting prevailing demand in the most costefficient way. AEMO then dispatches these generators into production (Martin and Rice,2012).

A dispatch price is determined every five minutes, and six dispatch prices are averaged every half-hour to determine the spot price for each trading interval for each of the regions of the NEM. AEMO uses the spot price as the basis for the settlement of financial transactions for all energy traded in the NEM. The Rules set a maximum spot price, also known as a Market Price Cap, of $\$ 12,500$ per megawatt hour (MWh). This is the maximum price at which generators can bid into the market and is the price automatically triggered when AEMO directs network service providers to interrupt customer supply in order to keep supply and demand in the system in balance(Skoufa and Tamaschke,2011).The Rules place a limit on the minimum spot price. This limit is called the Market Floor Price and is currently set at $-\$ 1,000$ per MWh. The Reliability Panel reviews the level of the Market Floor Price and Market Price Cap every two years.Operating the NEM involves conducting a sequence of activities to facilitate trade between the producers and wholesale consumers of electricity. These activities include establishing demand levels, receiving offers to supply from generators, scheduling generators, dispatching generators into production, calculating the spot price, measuring electricity use and financially settling the market. 
A typical level of demand for electricity across the NEM is approximately 25,000 megawatts on a business day of average temperatures(Ignatieva and Trück,2016).There are three types of bids or offers to supply - daily bids, re-bids and default bids. Daily bids are submitted before $12: 30 \mathrm{pm}$ on the day before supply is required, and are reflected in pre-dispatch forecasts. Generators may submit re-bids up until approximately five minutes prior to dispatch. In doing so, they can change the volume of electricity from what it was in the original offer, but they cannot change the offer price. Default bids are standing bids that apply where no daily bid has been made.

Australia after almost a decade of heated political debate has become the world's first developed nation to repeal carbon laws that put a price on greenhouse-gas emissions.In a vote that could highlight the difficulty in implementing additional measures to reduce carbon emissions ahead of global climate talks next year in Paris, Australia's Senate on Thursday voted 39-32 to repeal a politically divisive carbon emissions price that contributed to the fall from power of three Australian leaders since it was first suggested in 2007.Australia, the world's 12th largest economy, is one of the world's largest per capita greenhouse gas emitters due to its reliance on coal-burning power stations to power homes and industry. In 2011, daily emissions per head amounted to 49.3 kilograms (108 pounds), almost four times higher than the global average of 12.8 kilograms, and slightly ahead of the U.S. figure of 48.2 kilograms.

\section{Conclusion}

Australia is one of the countries that depends highly on energy to supply different economic sectors such as transportation, communication, security, health, delivery systems and etc. about $49 \%$ of Australia's energy is consumed from domestic production and 51\% from external sources via imports and the growth of its gross domestic product (GDP) is highly dependent on fossil fuels like black coal, brown coal, crude oil, iron ore, other ore, processed metal, uranium and liquefied natural gas, which are the countries natural and mineral sources and form the major sources of Australia's export earnings. In this paper various economic factors such as the impact of oil prices on gross domestic product (GDP), total and industrial energy consumption, inflation rate and unemployment rate are analyzed according to the elasticity method which is one of the important economic factors to understand the effects of oil prices on different economical sectors. It was realized that elasticity calculations was less than $1\left(\mathrm{E}_{\text {Total }}-\mathrm{GDP}<1\right)$ which means that Energy productivity (gross domestic product/energy consumption) has increased significantly and Australia is using 
systems with good efficiency and its total GDP is not highly dependent on total energy consumption. It can also be perceived that GDP is not dependent on oil prices and oil imports does not have negative effect on GDP.

In addition statistics showed that energy consumption in Australia has decreased in most states and territories which shows that government actions such as proper feed-in tariff (FIT) and tax systems as well as establishing laws for reducing greenhouse-gas emissions and boosting renewable energy technologies,had a good effect on optimal energy consumption.

\section{References}

[1] Demirbaş, A 2006, ‘Global Renewable Energy Resources’ ,Energy Sources, Part A: Recovery, Utilization, and Environmental Effects, vol. 28, pp. 779-792.

[2] Hoppe, T, Coenen, F, \&van den Berg, M 2016, 'Illustrating the use of concepts from the discipline of policy studies in energy research: An explorative literature review' ,Energy research \& social science, vol. 21, pp. 12-32.

[3] Panwar, N, Kaushik, S \&Kothari, S 2011, 'Role of renewable energy sources in environmental protection: a review' ,Renewable and Sustainable Energy Reviews, vol. 15, pp. 1513-1524.

[4] Demırbas, A 2016, 'Future energy systems' ,Energy Sources, Part A: Recovery, Utilization, and Environmental Effects, vol. 38, pp. 1721-1729.

[5] Jiménez-Rodríguez, R\&Sánchez, M 2005, 'Oil price shocks and real GDP growth: empirical evidence for some OECD countries', Applied economics, vol. 37, pp. 201-228

[6] Krishnan, R, 'Energy security through a framework of country risks and vulnerabilities' ,Energy Sources, Part B: Economics, Planning, and Policy, vol. 11, pp. 32-37.

[7] Australian Government, Department of Foreign Affairs and Trade, 'Australia in brief' viewed 21 Novamber 2016,<http://dfat.gov.au/aboutus/publications/pages/australia-in-brief.aspx $>$

[8] Hardisty, PE, Clark, TS \&Hynes, RG 2012, 'Life cycle greenhouse gas emissions from electricity generation: A comparative analysis of Australian energy sources' ,Energies, vol. 5, pp. 872-897.

[9] Xue-qian, F 2012, 'Renewable energy in Australia' ,Power Demand Side Management, vol. 4, p. 026.

[10] Alobaid, F, Mertens, N, Starkloff, R, Lanz, T, Heinze, C \&Epple, B 2017, 'Progress in dynamic simulation of thermal power plants', Progress in Energy and Combustion Science, vol. 59, pp. 79-162.

[11] Sahoo, AK, Sahu, NC, Sahoo, D, \&Pradhan, BB 2014, 'Mineral export and economic growth in India: evidence from VAR model analysis', Mineral Economics, vol. 27, pp. 51-58. 
[12]Bollen, B, Skully, M, Tripe, D,\&Wei, X 2015, 'The global financial crisis and its impact on Australian bank risk',International Review of Finance, vol. 15, pp. 89-111.

[13] Enegy policies of IEA countries, Australia 2012 review,viewed 30 November 2016,<https://www.iea.org/countries/membercountries/australia/>

[14] Australia, viewed 25 November 2016,<http://data.worldbank.org/country/australia>

[15] Azad, A, Rasul, M, Khan, M, Omri, A,Bhuiya, M \&Hazrat, M 2014, 'Modelling of renewable energy economy in Australia' ,Energy Procedia, vol. 61, pp. 1902 1906.

[16] Inflation data, viewed 20 December 2016, $<$ http://inflationdata.com/inflation/inflation_rate/historical_oil_prices_table.asp $>$.

[17] Australian Government, Department of the Enviroment and Energy, viewed 25 December2016, <http://www.environment.gov.au>.

[18] Taxes and Incentives for Renewable Energy, viewed 21 December2015, $<$ https:/home.kpmg.com/xx/en/home/insights/2015/09/taxes-and-incentivesfor-renewable-energy-2015.html $>$.

[19] Department of Industry, innovation and Science, viewed 20 December2016, $<$ www.industry.gov.au $>$.

[20] Trading

Economics, viewed January2016, $<$ http://www.tradingeconomics.com/australia/forecast $>$.

[21] Martin, NJ,\&Rice, JL 2012, 'Developing renewable energy supply in Queensland, Australia: A study of the barriers, targets, policies and actions', Renewable Energy, vol. 44, pp. 119-127.

[22] Skoufa, L \&Tamaschke, R 2011, 'Carbon prices, institutions, technology and electricity generation firms in two Australian states',Energy Policy, vol. 39, pp. 2606-2614.

[23] Ignatieva, K \&Trück, S 2016, 'Modeling spot price dependence in Australian electricity markets with applications to risk management', Computers \& Operations Research, vol. 66, pp. 415-433. 